\title{
Integrating Technology, English, and Communication Courses for First-Year Technology Students
}

Amelia Chesley, Purdue University

Prof. Nathan Mentzer, Purdue University - West Lafayette

Nathan Mentzer is an assistant professor in the College of Technology with a joint appointment in the College of Education at Purdue University. Hired as a part of the strategic P12 STEM initiative, he prepares Engineering/Technology candidates for teacher licensure. Dr. Mentzer's educational efforts in pedagogical content knowledge are guided by a research theme centered in student learning of engineering design thinking on the secondary level. Nathan was a former middle and high school technology educator in Montana prior to pursuing a doctoral degree. He was a National Center for Engineering and Technology Education (NCETE) Fellow at Utah State University while pursuing a Ph.D. in Curriculum and Instruction. After graduation he completed a one year appointment with the Center as a postdoctoral researcher.

\section{Mr. Andrew Jackson, Purdue University - West Lafayette}

Andrew Jackson is currently pursuing a PhD in Technology through Purdue's Polytechnic Institute. His previous middle school teaching experience informs his role as a graduate teaching assistant for TECH 120, an introductory course in design thinking. He recently completed his Master of Science in Technology Leadership and Innovation from Purdue University with a thesis investigating middle school engineering self-efficacy beliefs. His research interests are engineering self-efficacy, creativity, and decision making.

\section{Dr. Dawn Laux}

Dawn Laux is a Clinical Assistant Professor in the Department of Computer and Information Technology (CIT) at Purdue University. She has been with the University since 2007 and is responsible for teaching database fundamentals courses and introductory technology courses. Laux has 10 years of industrial experience in the information technology field, and her research area of interest includes technology readiness, the social impacts of technology, and increasing interest in the field of computing.

Mr. Max Renner, Purdue Polytechnic Institute, Purdue University 


\title{
Integrating Technology, English, and Communication Courses for First-Year Technology Students
}

\begin{abstract}
This work in progress describes a large-scale, inter-departmental course integration for first-year Technology majors. Undergraduate student experience during the first year has been linked to success throughout college. The current work-in-progress extends existing research regarding the first-year experience by documenting the implementation and effects of a large-scale first-year course integration. This Integrated First-Year Experience is a new large-scale course integration being implemented at a large public research university. Large-scale integration on this level is an intervention in the traditional university model, which often times includes a heavy, discipline-based segmentation of coursework. In this new arrangement, students in an introductory Technology course are enrolled together in either an introductory Communication course or an introductory English composition course. This article reports on the establishment of this course integration, including our efforts to document and analyze the experience. The article begins to explore what differences this arrangement of courses has made for students and instructors, with a focus toward if and how their formal integration may improve students' learning, academic engagement, and sense of community.
\end{abstract}

\section{Introduction}

First-year undergraduate experience, both social and academic, has been strongly linked to success throughout students' subsequent college years. As a result, many institutions have attempted to improve retention and persistence among their student bodies by implementing a variety of programs aimed at improving the first-year experience. Common means of increasing student engagement and persistence in the first year of undergraduate education include first-year seminars and other programs, residential or academic learning communities, and course integration. Though these methods of managing and enhancing first-year undergraduate experience in general have been researched, large-scale partnered-teaching efforts that span more than one institutional department are relatively uncommon in the context of large public research universities. Purdue Polytechnic, in conjunction with the Departments of English and Communication at Purdue University, has implemented a new Integrated First-Year Experience among 3 introductory freshman courses-Introductory Composition, Fundamentals of Speech Communication, and Design Thinking in Technology. In total, the integration involved over 500 first-year students, 34 instructors, and 3 departments across the university; the integration emphasizes intersections between humanities and STEM disciplines and provide an "integrated, holistic approach to coursework," "innovative learning environments," and "a context-rich application of English, Communications and Technology" 1. Specifically, this project aims to improve students' writing skills, oral communication skills, and presentation skills by reinforcing the importance of these skills in realistic, project-based design contexts. Administrators and instructors within all 3 departments hope the integration will improve students' learning in all disciplines, increase academic engagement overall, and create a stronger sense of community among students.

Large-scale integration on this level is an intervention in the traditional university model, which often times includes strict discipline-based divisions of coursework. In this new arrangement, students in each integrated introductory Technology class are also enrolled in either 
an introductory Communication course or an introductory English course. Administrators from each department worked to develop initial outlines and structures that would facilitate curricular overlap and connection across each trio of classes. Scheduling and classroom spaces were arranged so that each pair of courses (Technology and English, or Technology and Communication) would meet consecutively once per week in the same shared classroom space. Instructors in each "trio" of courses were encouraged to collaboratively explore and implement effective ways of reinforcing and integrating concepts and curriculum from the course they were paired with in their own courses. This article reports on the establishment of this course integration and begins to explore not only how instructors approached these teaching opportunities, but also what differences their efforts made. We focus on both how this project affected students and instructors, and pay special attention to if and how the formal integration of these courses improves students' learning, academic engagement, and sense of community. What follows is a brief overview of existing research; some detailed documentation of the motivation, history, and timeline of the Integrated First-Year Experience; preliminary discussion about the project's research agenda, limitations, and current status; and a brief view of the project's future development.

\section{Existing Research on First-Year Undergraduate Experience}

First-year seminar programs, residential and academic learning communities, and course integration efforts have been studied and implemented at various levels within educational institutions around the world. Many factors underlying student success in the first-year, including measures of collaborative learning and connectedness ${ }^{2}$, the importance of self-efficacy and optimism $^{3,4}$, the role of social support, ${ }^{5}$ and the construction of student communities, ${ }^{6-8}$ are present in existing literature. Some institutions require students to enroll in courses meant to help them adjust to college life: low-credit academic skills courses, First-Year Seminars, orientations, or other similar courses ${ }^{9,10}$. Enke $^{10}$ cited a National Survey of First-Year Seminars from 2006, which reported that campuses with these types of First-Year programs tend to see "increased satisfaction with faculty and the institution, improved retention to the sophomore year and persistence to graduation, increased involvement in campus activities and use of campus services, increased out-of-class student/faculty interaction, and improved academic ability and grade point average" (p. 78).

Learning communities are another way academic institutions attempt (with mixed results) to foster community and engagement, with hopes of improving retention and persistence among students ${ }^{6,7}$. Smith ${ }^{6}$ traced connectedness among residential learning communities. Recent research on classroom integration within STEM fields, especially in K-12 settings, indicates that course integration within STEM disciplines - e.g. integrating math/engineering, science/math, or technology/science - has potential for improving learning in both subjects ${ }^{11}$.

Within engineering education specifically, attempts have also been made to reinforce the first-year experience for students. Dym et al. ${ }^{12}$ described and evaluated how the core principles of engineering and design are often taught via project-based learning. These authors note an increase in "corner-stone (design) courses"-foundational, introductory courses, analogous to more traditional "capstone" courses, but specifically geared toward first-year students - and observe that these corner-stone courses have been "motivated by an awareness of the curricular disconnect with first-year students who often did not see any engineering faculty for most of their first two years of study" (p. 103). Efforts to re-envision engineering programs and integrate core principles of engineering and design more consistently throughout students' undergraduate 
careers aim to improve and make engineering education more effective overall, but may not always succeed. Often such efforts are highly demanding in terms of logistical planning, institutional support, and instructor commitment, as Hirsch et al. ${ }^{13}$ recognized. Combining resources across colleges or schools provides great opportunities for interdisciplinary, crosscollege instruction, but also comes with complexities and potential costs.

Not unexpectedly Honey, Pearson \& Schweingruber's ${ }^{11}$ findings and discussion "suggest that integration can lead to improved conceptual learning in the disciplines but that the effects differ, depending on the nature of the integration, the outcomes measured, and the students' prior knowledge and experience" (p. 52). The STEM integration report also acknowledged that "very little is known about how to organize curriculum and instruction so that emerging knowledge in different disciplines will mesh smoothly and at the right time to yield the kind of integration that supports coherent learning" and importantly warned, "the danger is that one or more of the 'integrated' disciplines will receive short shrift in its development" (p. 53). Early in the development of this Integrated First-Year Experience, administrators admitted concern about the potential limitations of isolating students within the Purdue Polytechnic Institute. Students enrolled in the integrated sections could miss out on interactions with students outside their college/field. Additionally, as the preliminary results indicate below, some instructors also feared the imbalances Honey, Pearson \& Schweingruber ${ }^{11}$ discussed.

The current project extends first-year experience research with a focus on interdisciplinary course integration. Our Integrated First-Year Experience is not a learning community or an "extra" introductory college skills class. Nor is this program merely interested in integration within STEM fields, but rather a concerted effort among three separate university departments to tie essential skills and concepts from the humanities, along with skills and concepts important to STEM fields, to realistic global problems and contexts.

\section{Background and Logistics}

At this public research institution, the introductory Communication course and the introductory English course are required of nearly all students. The introductory Technology course is required of every first-year student within the Purdue Polytechnic Institute. For this new course integration, administrators and instructors from the Polytechnic Institute, the Department of English, and the Department of Communication collaborated to teach 13 sections of paired Technology, English, and Communication courses. Additional non-integrated sections ( 3 of Technology and multiple English and Communication) were also offered and taught separately, as usual. Although the majority of Technology sections were integrated during Fall semester, scheduling conflicts, different course requirements, and other potential factors meant that not all freshmen students within the Polytechnic Institute selected this option.

Motivations for this collaboration grew out of widespread (if perhaps anecdotally supported) recognition among instructors that Technology students often seem to struggle effectively expressing their design ideas, whether in writing or formal presentations. Conversely, the work students engage with in English and Communication courses can sometimes seem to lack a realistic, meaningful purpose or context outside of an academic classroom setting. The opportunity for integrating these disciplines potentially answers both needs. Before the semester began, teaching administrators and mentors from Technology, Communication, and English shared resources and mapped out a few specific ways instructors would be encouraged and expected to connect their courses. 
During this fall semester, the 40 students in each integrated version of the introductory Technology course were divided into 2 groups of 20. One group was enrolled together in the required introductory Communication course, and the other in the required introductory English course. Minimal adjustments were made to the usual class size of the Communication course, which was traditionally 24 students. Adjustments were also made to the meeting locations of Communication and English courses so that one class day per week could be held in one of two brand new technology classrooms. These spaces were designed with ample space for group work, multiple projector screens, whiteboards, laptop carts, and plenty of power outlets for students' electronic devices. Each "trio" of course sections included one Technology section, one English section, and one Communication section, all linked together by virtue of including the same students and meeting at adjacent times in the same classroom space. Table 1 (below) presents more detail about each course. Table 2 demonstrates the schedules for a typical integrated "trio."

All three programs have recently undergone an institutional assessment of program effectiveness - the Instruction Matters: Purdue Academic Course Transformation (IMPACT) initiative (informed by Deci \& Ryan ${ }^{14}$ ), and have accordingly redesigned their curricula to be more student-centered. We expect that these adjustments in curricula and objectives will also affect how well each section's instructors are able to create synergy between the sections they are teaching, Furthermore, the programmatic structures of the three courses may also challenge instructors' efforts to integrate content and teaching. The relatively set, centralized syllabus for Communication and Technology courses allowed for pre-planned integration at the level of class activities and course projects. In contrast, the relative flexibility and high level of diversity among English instructors' syllabi meant integration between these two courses required more mid-semester adjustments and day-to-day work to promote; in designing the integrated experience between each Technology and English, pairs of instructors were responsible for negotiating the connected content.

\begin{tabular}{|r|c|c|c|}
\hline & Technology course & English course & Communication course \\
\hline Credit hours & 3 & 4 & 3 \\
\hline Max. class size & 40 students & 20 students & 3 \\
\hline Meetings/week & 2 & 4 & students \\
\hline Meeting spaces & Large technology lab & $\begin{array}{c}\text { Traditional classroom, conference room, } \\
\text { traditional computer lab, and the } \\
\text { technology lab }\end{array}$ & $\begin{array}{c}\text { Traditional classroom and } \\
\text { the technology lab }\end{array}$ \\
\hline $\begin{array}{r}\text { Course } \\
\text { structure }\end{array}$ & $\begin{array}{r}\text { Flexible, centralized } \\
\text { course-wide syllabus }\end{array}$ & $\begin{array}{r}\text { 8 variations on course-wide goals, } \\
\text { instructors create individual } \\
\text { custom syllabi }\end{array}$ & $\begin{array}{c}\text { Strict, centralized } \\
\text { course-wide syllabus }\end{array}$ \\
\hline
\end{tabular}

Table 1: Characteristics and Meeting Details of each Integrated Introductory Course, Fall 2015 


\begin{tabular}{|c|c|c|c|}
\hline Meeting days & Technology section & English section & Communication section \\
\hline Monday & $\begin{array}{c}\text { 9:30am, technology lab } \\
\mathbf{n}=\mathbf{4 0}\end{array}$ & $\begin{array}{c}\text { 10:30am, technology lab } \\
\qquad \mathbf{n = 2 0}\end{array}$ & $\begin{array}{l}\text { 10:30am, traditional classroom } \\
\qquad \mathbf{n}=\mathbf{2 0}\end{array}$ \\
\hline Tuesday & $\mathrm{X}$ & $\begin{array}{c}\text { 10:30am, conference room } \\
\mathbf{n}=\mathbf{1 0}\end{array}$ & $\mathrm{X}$ \\
\hline Wednesday & $\begin{array}{c}\text { 9:30am, technology lab } \\
\mathbf{n}=\mathbf{4 0}\end{array}$ & $\mathrm{X}$ & $\begin{array}{c}\text { 10:30am, technology lab } \\
\mathbf{n}=\mathbf{2 0}\end{array}$ \\
\hline Thursday & X & $\begin{array}{c}\text { 10:30am, computer lab } \\
\mathbf{n}=\mathbf{2 0}\end{array}$ & $X$ \\
\hline Friday & $\mathrm{X}$ & $\begin{array}{c}\text { 10:30am, conference room } \\
\mathbf{n}=\mathbf{1 0}\end{array}$ & $\begin{array}{l}\text { 10:30am, traditional classroom } \\
\qquad \mathbf{n}=\mathbf{2 0}\end{array}$ \\
\hline
\end{tabular}

Table 2: Sample Schedule and Meeting Arrangements for a Typical Integrated "Trio." Shaded blocks indicate which courses share classroom space on which days.

\section{Methods}

This research project in progress uses mixed methods to document and investigate what difference the course integration described above makes for students and instructors, with a focus on if and how the formal integration of these courses will improve students' learning, academic engagement, and sense of community. The administrators and instructors who supported, planned, and prepared the framework for this project also explicitly provided for the documentation and analysis of its implementation. Participants and researchers from all three departments collaborated in shaping the goals and approach of not only the integration itself, but ways it should be recorded and studied. Our research will inform the development of future interdisciplinary integration at our own institution and also serve as a model for similar projects being planned or implemented at other institutions.

The questions our research project seeks to answer are:

1.a. Do students learn writing skills more effectively in integrated sections than in non-integrated sections?

b. Do students learn communication skills more effectively in integrated sections than in non-integrated sections?

c. Do students learn design thinking more effectively in integrated sections than in non-integrated sections?

2.Will the integrated courses increase students' perceived learning and sense of self-efficacy?

3.Will the integrated courses help students engage with and value the broader academic community and mission of the University?

4.How and in what ways are English, Communication, and Technology courses being integrated?

5.Will meeting in a shared space once each week emphasize the integrated nature of these courses and therefore benefit students?

Data collection began with the Fall 2015 semester, in late August. We recruited students, instructors, and administrators in all three departments to participate and contribute data to the project. The population of potential participants included students and instructors in all 13 integrated sections of each course: a total of 34 instructors and 520 students. In addition, we planned to include a small sample of non-integrated classes - the 3 additional Technology sections, as well as 4 Communication, and 4 English sections - as a 'comparison group' against which to measure the materials collected from students and instructors in integrated sections of 
each course. With the guidance of department administrators, we selected instructors with a range of teaching experience similar to that of those instructors teaching within the integrated program.

Table 3 collates each of our data collection points with the research questions that data will be used to answer. Some data were collected as a matter of normal educational procedure: student work, course evaluations, attendance, drop rates, and other student surveys. Student and instructor focus groups were conducted at regular intervals over the course of the semester. Final student writing, presentations, and design projects were collected after the end of the Fall 2015 semester.

The sections that follow include additional detail about each subset of data, how it was collected, and our plans to analyze it.

\section{Student Data}

Data collected from students included survey responses, focus group responses, and anonymized student work as completed in all three courses. For recruitment of student participants, research assistants visited all relevant sections of each course to introduce the project and invite students to participate by attending focus groups and allowing the collection of anonymized student work (including survey responses). Elaboration on each category of data and corresponding methods of collection are included below.

\section{Survey Responses}

As part of their work in Design Thinking and Technology, all students complete various pre- and post-semester surveys, including a decision-making strategies survey ${ }^{15}$, a Collaborative Learning and Commitment Survey ${ }^{2}$, the Comprehensive Assessment of Team Member Effectiveness (CATME) survey ${ }^{17,18}$, and the Situational Motivation Scale (SIMS) survey ${ }^{16}$. These are administered as part of normal classroom procedures and annually used for course improvements. All student survey responses were collected and collated in a single spreadsheet, coded with anonymous student ID numbers, and quantitatively analyzed. Two additional sets of survey responses - to the IMPACT survey and regular end-of-semester student course evaluations - were collected from the university's Center for Instructional Excellence, with identifying data removed.

\section{Student Focus Groups}

Students from all 13 integrated sections were invited to participate in a series of focus groups during the semester. Originally we planned to hold two series of focus groups: 3 or 4 near the middle of the semester and 3 or 4 near the end. Scheduling delays and highly uneven levels of participation led to a revision of this plan, and semi-structured focus group interviews were held regularly over the second half of the semester, during weeks 7, 9, 11, 13, and 16. Weeks 7 and 9 saw an over-representation of Communication students, with few English students attending. This initial imbalance evened out in later focus groups meetings. ${ }^{*}$ We recorded the audio of each focus group discussion have begun to code these recordings for emergent themes.

\footnotetext{
${ }^{*}$ The introductory Communication course includes a requirement to participate in an "Outside Research Activity." These focus group meetings were advertised as one way in which students could fulfill this requirement. No equivalent incentive is built in to the introductory English course, and this most likely explains the uneven participation in our early focus groups.
} 


\begin{tabular}{|c|c|}
\hline Research Question & Relevant Data \\
\hline \multirow[t]{2}{*}{$\begin{array}{l}\text { 1a. Do students learn writing skills more effectively in integrated } \\
\text { sections than in non-integrated sections? }\end{array}$} & $\begin{array}{l}\text { Existing research writing assignment in } \\
\text { English course }\end{array}$ \\
\hline & $\begin{array}{l}\text { Existing writing assignments in Technology } \\
\text { course }\end{array}$ \\
\hline \multirow[t]{2}{*}{$\begin{array}{l}\text { 1b. Do students learn communication skills more effectively in } \\
\text { integrated sections than in non-integrated sections? }\end{array}$} & $\begin{array}{l}\text { Existing presentation assignments in } \\
\text { Communications course }\end{array}$ \\
\hline & $\begin{array}{l}\text { Existing presentation assignment in } \\
\text { Technology course }\end{array}$ \\
\hline \multirow{2}{*}{$\begin{array}{l}\text { 1c. Do students learn design thinking more effectively in integrated } \\
\text { sections than in non-integrated sections? }\end{array}$} & Existing design task in Technology course \\
\hline & $\begin{array}{l}\text { Student responses to a decision making } \\
\text { strategies survey }{ }^{15}\end{array}$ \\
\hline \multirow[t]{2}{*}{$\begin{array}{l}\text { 2. Will the integrated courses increase students' perceived learning } \\
\text { and sense of self-efficacy? }\end{array}$} & $\begin{array}{l}\text { Student responses to the IMPACT Survey } \\
\text { (informed by Deci \& } \text { Ryan }^{14} \text { ) }\end{array}$ \\
\hline & Student focus group interviews \\
\hline \multirow[t]{8}{*}{$\begin{array}{l}\text { 3. Will the integrated courses help students engage with and value } \\
\text { the broader academic community and mission of the University? }\end{array}$} & $\begin{array}{l}\text { Student responses to the Collaborative } \\
\text { Learning and Commitment Survey }\end{array}$ \\
\hline & Student focus group interviews \\
\hline & End-of-semester Student Course Evaluations \\
\hline & $\begin{array}{l}\text { Student responses to team member } \\
\text { effectiveness surveys (CATME) }\end{array}$ \\
\hline & Attendance rates \\
\hline & Drop/fail/withdrawal rates \\
\hline & Student responses to the IMPACT Survey \\
\hline & $\begin{array}{l}\text { Student responses to the Situational } \\
\text { Motivation Scale }{ }^{16}\end{array}$ \\
\hline \multirow{5}{*}{$\begin{array}{l}\text { 4. How and in what ways are English, Communication, and } \\
\text { Technology courses being integrated? } \\
\text { 5. Will meeting in a shared space once each week emphasize the } \\
\text { integrated nature of these courses and therefore benefit students? }\end{array}$} & Administrator focus group interviews \\
\hline & Instructor focus group interviews \\
\hline & Student focus group interviews \\
\hline & Classroom Observations \\
\hline & Course materials/syllabi \\
\hline
\end{tabular}

Table 3: Research Questions and Corresponding Data Collected, Fall 2015

\section{Student Work}

With permission from students, selections of their coursework, including research writing, presentations, design tasks, and final projects were collected to assess student learning. Final presentations in both the Technology course and Communication course are regularly recorded, and we plan to code these recordings according to the rubrics that Communication instructors regularly use ${ }^{19}$. We will compare the resulting data between integrated and non-integrated sections. Writing and design projects will be similarly evaluated using existing standardized 
rubrics, vetted and provided by each department. The resulting scores from all three types of student work will be compared with similar existing data from past semesters. Using internal rubrics to evaluate student work will allow us to compare scores longitudinally.

\section{Instructor Data}

Data collected from instructors included journal responses, focus group responses, and selected course materials - primarily course syllabi and aggregate attendance records. With instructors' and supervisors' permissions, we also observed selected classrooms. All instructors were invited via email to participate in this project at each stage of data collection.

Instructor Journals

Simple journal prompts were distributed to all instructors teaching as part of the Integrated FirstYear Experience at three specific points in the semester, one as the course began, one around mid-term, and one during the final week. All three sets of prompts included four brief questions about instructors' efforts at integration, about student abilities and confidence, and about the shared classroom space. More than two-thirds of all instructors replied to each journal prompt, with responses of varying lengths. Deidentified responses will be coded for emergent themes.

\section{Instructor Focus Groups}

We held regular focus group interviews for instructors and administrators. These were semistructured interviews aimed at documenting instructor's experiences. Audio from these meetings was recorded and will be coded for emergent themes during Spring 2016.

\section{Classroom Observations}

To document what kinds of integration and overlap were created in each section, and to sense whether meeting in a shared space once each week made integration easier for instructors, researchers observed a targeted sample of integrated classes at a few points during the semester. As previously mentioned, researchers planned to observe integrated and non-integrated sections of each course, Technology, Communication, and English. However, logistical and scheduling conflicts prevented additional observations, and we were ultimately unable to observe any nonintegrated sections of the Communication class. In total, observed sections included:

3 integrated Technology sections

3 non-integrated Technology sections

3 integrated Communication sections

3 integrated English sections

4 non-integrated English sections.

Observers watched for references made by the instructors to the other integrated classes, to those other classes' assignments, to the community being built, and to students' engagement beyond the classroom. Field notes from these observations will help us compare the various ways these courses are being integrated. Another emerging purpose for these observations was to notice opportunities where future connections could be made between concepts and curricula of all three courses. These ideas will assist administrators and future instructors in refining their integration efforts for the coming year. 


\section{Results}

The data described above have not been fully analyzed at this stage, but from the student and instructor responses collected and recorded so far, we might sketch a few preliminary conclusions. See Table 4 for an overview of what has been analyzed thus far, and Table 5 for a brief breakdown of preliminary results organized by research question. Responses to this Integrated First-Year Experience have been mixed on among both student and instructor perspectives.

\begin{tabular}{|l|l|l|}
\hline & \multicolumn{1}{|c|}{ Currently Under Analysis } & \multicolumn{1}{c|}{ To Be Analyzed } \\
\hline Student Data Sources & $\begin{array}{l}\text { Student survey responses } \\
\text { Student focus group recordings }\end{array}$ & Student work \\
\hline Instructor Data Sources & Instructor focus group recordings & $\begin{array}{l}\text { Instructor journal responses } \\
\text { Classroom observation notes }\end{array}$ \\
\hline
\end{tabular}

Table 4: Status of Data Analysis as of Spring Semester, 2016

Instructor responses in journaling and focus groups reflect high hopes and some ambition and excitement. Those that feel most positively report holding regular meetings with the instructors in their trio. Most instructors indicated that their students seemed incredibly comfortable with their classmates, which indicates that the integrated classes are contributing to more connectedness among those enrolled. Of 14 instructors ( 7 from English, 4 from Communication, and 3 from Technology) who responded to the final journal prompts, 10 instructors indicated that teaching an integrated course like this one was pedagogically sound and rewarding in some fashion, either for themselves or for their students. These 10 instructors $(5$ from English, 3 from Technology, and 2 from Communication) all expressed willingness to teach in the same arrangement of integrated courses in future semesters, though 1 Technology instructor and 1 English instructor did place conditions on this. The other 4 responding instructors cited various concerns related to underprepared students, lack of support and communication among co-instructors and administrators, and what appeared to them to be poor planning. Some instructor responses hint at confusion and uncertainty about the logic, fairness, and sustainability of this interdisciplinary partnership. There are hesitations and doubts about the ways each course is structured in relation to the others, and about instructors' abilities to successfully collaborate. Some instructors also expressed worries about the balance of autonomy in a linked course, reporting that they felt more pressure to transform their teaching to match their co-instructors' than seemed reasonable. Experiences and reactions were mixed; analyzing responses and results according to each trio will tell us more about which factors influenced instructors, and how.

Student responses ranged from somewhat appreciative to frustrated, disappointed, and even angry. In focus group meetings, the most vocal students were those with complaints about perceived miscommunication (or lack of communication) among the instructors of the integrated classes, about seemingly contradictory assignment guidelines, and about the course workload. That these most vocal responses are more negative is somewhat expected and perhaps normal, particularly for first-year students with high expectations for a new semester. Not all insights from students will prove relevant; data from the rest of our research (surveys, assignments, etc.) will be essential for triangulating what we have heard in the focus group interviews. Whether student work reflects greater improvement over all integrated sections remains to be seen; instructors' observations here have so far been mixed. 
The mixed levels of engagement from instructors and the mixed responses overall are in line with our initial expectations. As we collate these data according to sections and trios, patterns and correlations may emerge to tell us more about what has been effective, for whom, and why.

\begin{tabular}{|c|c|}
\hline Research Question & Anticipated and Preliminary Results \\
\hline $\begin{array}{l}\text { 1a. Do students learn writing skills more effectively in } \\
\text { integrated sections than in non-integrated sections? }\end{array}$ & $\begin{array}{l}\text { From instructor comments in journal responses and } \\
\text { focus groups, students' writing skills seemed } \\
\text { disappointing when compared with instructors' } \\
\text { previous experiences teaching college freshmen. Once } \\
\text { student work has been collected, anonymized, } \\
\text { evaluated, and compared to work from non-integrated } \\
\text { sections of all three courses, we will know more. }\end{array}$ \\
\hline $\begin{array}{l}\text { 1b. Do students learn communication skills more } \\
\text { effectively in integrated sections than in non-integrated } \\
\text { sections? }\end{array}$ & $\begin{array}{l}\text { Both instructors and students commented in focus } \\
\text { groups that giving presentations was less intimidating } \\
\text { and that students felt or seemed more confident. } \\
\text { Coding and analyzing recordings will allow us to } \\
\text { confirm this. }\end{array}$ \\
\hline $\begin{array}{l}\text { 1c. Do students learn design thinking more effectively } \\
\text { in integrated sections than in non-integrated sections? }\end{array}$ & $\begin{array}{l}\text { Analysis of student projects are needed before this } \\
\text { becomes clear. }\end{array}$ \\
\hline $\begin{array}{l}\text { 2. Will the integrated courses increase students' } \\
\text { perceived learning and sense of self-efficacy? }\end{array}$ & $\begin{array}{l}\text { Instructor responses in focus groups and journals } \\
\text { reflect that students in integrated sections grew more } \\
\text { comfortable with each other and more confident as a } \\
\text { result. As we analyze students' survey responses, we } \\
\text { will fill in more answers here. }\end{array}$ \\
\hline $\begin{array}{l}\text { 3. Will the integrated courses help students engage with } \\
\text { and value the broader academic community and } \\
\text { mission of the University? }\end{array}$ & $\begin{array}{l}\text { Most instructors reported higher than normal } \\
\text { attendance rates and greater participation in class, } \\
\text { which could signify increased engagement. Some } \\
\text { students commented that they felt a good sense of } \\
\text { community with classmates in these courses. }\end{array}$ \\
\hline $\begin{array}{l}\text { 4. How and in what ways are English, Communication, } \\
\text { and Technology courses being integrated? }\end{array}$ & $\begin{array}{l}\text { As anticipated, there have been a range of successful } \\
\text { and less-successful integration attempts among } \\
\text { instructors; a few instructors were enthusiastic, a few } \\
\text { were resistant. Students seem to sense this and report a } \\
\text { mix of appreciation, frustration, and apathy. } \\
\text { Observations suggest rich potential for } \\
\text { continued/further integration at the classroom level, } \\
\text { depending on timing and priorities. Instructor journal } \\
\text { responses also suggest modifications that may improve } \\
\text { the integration. }\end{array}$ \\
\hline $\begin{array}{l}\text { 5. Will meeting in a shared space once each week } \\
\text { emphasize the integrated nature of these courses and } \\
\text { therefore benefit students? }\end{array}$ & $\begin{array}{l}\text { Meeting in a shared space seems to be unnecessary but } \\
\text { convenient for some. Some instructors occasionally } \\
\text { took advantage of this time to meet and transition. } \\
\text { Students were able to use this time to collaborate. } \\
\text { However, the new classroom spaces posed challenges } \\
\text { in layout and size for the smaller Communications and } \\
\text { English classes. }\end{array}$ \\
\hline
\end{tabular}

Table 5: Anticipated/Preliminary Results, by Research Question 


\section{Discussion and Conclusion}

This documentation and research will assist administrators and instructors in preparing for the second implementation of the Integrated First-Year Experience, currently planned for Fall 2016. However, there are limitations to what we have been and will be able to learn from this research. We relied on volunteer samples of both students and instructors, which means the focus groups, surveys, and student work we collected will be necessarily incomplete. Furthermore, a large-scale pedagogical initiative like this comes with complex variables and contingencies that will be difficult to control for. All three of the courses involved in this course integration, for example, have recently undergone an institutional assessment of program effectiveness and redesigned their curriculum to be more student-centered. In past years, the introductory Technology course met only once per week, while during the Fall 2015 semester it met twice per week, which changed the pacing and dynamics of the course significantly. Introductory Communication courses no longer require students to create formal written outlines for every presentation, which may make comparing work from this year to work from last year somewhat problematic. Instructors in the Department of English are remarkably free to adjust their teaching plans from year to year and across sections, which presents another challenge to the matter of comparing student work. As we continue to research the next iteration of this program, clearer comparisons and more thoroughly consistent analysis will be increasingly possible.

Despite these limitations, our research and documentation of this inaugural Integrated First-Year Experience has illuminated aspects of this endeavor that are working, other aspects that seem to have potential, and some aspects that either may not work or need significant revision before they will have the intended effect of improving student experience both in learning and engagement. There is a wide spectrum of attitudes towards this interdisciplinary collaboration, and instructors are engaging with the Integrated First-Year Experience at various levels. The general sense of focus group data indicates an overall attitude held by students, instructors, and administrators that this integration has potential and details must be refined.

References

1. Lincoln, Steven. (2015, May 15). Trustees approve Purdue Polytechnic Institute name. Purdue University News.

2. Laux, D. (2014). A model for measuring student persistence through collaborative learning (Doctoral Dissertation). Retrieved from Digital Repository at Iowa State University. (Paper 14175)

3. Chemers, M. M., Hu, L. T., \& Garcia, B. F. (2001). Academic self-efficacy and first year college student performance and adjustment. Journal of Educational Psychology, 93(1), 55-64.

4. Hutchison, M. A., Follman, D. K., Sumpter, M., \& Bodner, G. M. (2006). Factors influencing the selfefficacy beliefs of first-year engineering students. Journal of Engineering Education, 95(1), 39-47. doi: 10.1002/j.2168-9830.2006.tb00876.x

5. Wilcox, P., Winn, S., \& Fyvie- Gauld, M. (2005). 'It was nothing to do with the university, it was just the people': the role of social support in the first- year experience of higher education. Studies in Higher Education, 30(6), 707-722.

6. Smith, R. (2011). Learning Community Transitions in the First Year: A Case Study of Academic and Social Network Change. Journal of The First-Year Experience \& Students in Transition, 23(2), 13-31.

7. Garland, L. \& Kolkmeyer K. (2011). A Culture of Conversation: Faculty Talk as Meaningful Assessment of Learning Communities. Teaching English in the Two-Year College 38(3), 231-243.

8. Tinto, V., \& Goodsell, A. (1994). Freshman interest groups and the first-year experience: Constructing student communities in a large university. Journal of The First-Year Experience \& Students in Transition, 6(1), 7-28. 
9. Gardner, A. F. (2013). Predicting Community College Student Success by Participation in a First-Year Experience Course. (Unpublished dissertation). Western Carolina University, Cullowhee, NC.

10. Enke, K. A. E. (2011). Lasting Connections: A Case Study of Relationships Formed During a First-Year Seminar Course. Journal of The First-Year Experience \& Students in Transition, 23(1), 75-102.

11. Honey, M., Pearson G., \& Schweingruber, H. (Eds.). (2014). STEM Integration in K-12 Education: Status, Prospects, and an Agenda for Research. Washington, DC: The National Academies Press.

12. Dym, C. L., Agogino, A. M., Eris, O., Frey, D. D., \& Leifer, L. J. (2005). Engineering design thinking, teaching, and learning. Journal of Engineering Education, 94, 103-119.

13. Hirsch, P.L., Schwom, B.L., Yarnoff, C., Anderson, J.C., Kelso, D.M., Olson, G.B., and Colgate, J.E., "Engineering Design and Communication: The Case for Interdisciplinary Communication," International Journal of Engineering Education, Vol. 17, Nos. 4 and 5, 2001, pp. 343-348.

14. Deci, E. L., \& Ryan, R. M. (2000). The "what" and "why" of goal pursuits: Human needs and the selfdetermination of behavior. Psychological Inquiry, 11, 227-268.

15. Jackson, A., Mentzer, N., \& Zissimopoulos, A. N. (2015). Factors of Group Design Decision Making. ASEE Annual Conference \& Exposition.

16. Guay, F., Vallerand, R. J., \& Blanchard, C. (2000). On the assessment of situational intrinsic and extrinsic motivation: The situational motivation scale (SIMS). Motivation \& Emotion, 24(3), 175-213.

17. Ohland, M. W., Loughry, M. L., Woehr, D. J., Finelli, C. J., Bullard, L. G., Felder, R. M., Layton, R. A., Pomeranz, H. R., \& Schmucker, D. G. (2012). The comprehensive assessment of team member effectiveness: Development of a behaviorally anchored rating scale for self and peer evaluation. Academy of Management Learning \& Education, 11 (4), 609-630.

18. Loughry, M. L., Ohland, M. W., \& Moore, D. D. (2007). Development of a theory-based assessment of team member effectiveness. Educational and Psychological Measurement, 67, 505-524

19. Morgan, M., \& Natt, J. (2015). Effective presentations: 2015-2016 edition. Boston, MA: Cengage. 